\title{
Knowledge of Family Health Strategy professionals regarding the Academia da Cidade Program (ACP) in the city of Recife
}

\author{
Conhecimento dos profissionais da Estratégia Saúde da Família sobre o \\ Programa Academia da Cidade no Recife
}

Vanessa Luiza Gomes de Moura’', Emmanuelly Correia de Lemos², Juliana Ribeiro Falcão Cavalcanti, Raquel Bezerra Pajeú1, Vandepaula Moraes Campos de Melo², Letícia Lemos Ayres da Gama Bastos²

\begin{abstract}
The aim of this study was to assess the knowledge of Family Health Strategy (FHS) professionals regarding the Academia da Cidade Program (ACP) in Recife. This is a descriptive, cross-sectional study using a quantitative approach at family health units (FHUs) in Recife, located at most $2 \mathrm{~km}$ from ACP centers. A total of 203 FHS professionals participated in the research. The data collection instrument consisted of a self-applied questionnaire. The variables investigated were related to sociodemographic and professional training aspects and knowledge of the ACP. Data collection occurred between July and August 2015, in pre-arranged visits at FHUs. The data were tabulated using the EpiDataEntry program and SPSS software. Of the professionals interviewed, $89.2 \%$ were women, $37 \%$ were aged between 30 and 39 years, $95 \%$ reported knowing the ACP, $76.5 \%$ knew the centers in their district, and $48.4 \%$ declared that they knew the objectives of the program. On the other hand, other than the centers, $58.9 \%$ do not know other locations where ACP activities are held or all the activities promoted by the Program. Thus, it was found that the FHS professionals are familiar with the ACP and its objectives, as well as the centers in their health district. However, fewer than half know other locations where the program functions, such as FHUs, in addition to recognizing only some of the activities as belonging to the ACP. Thus, there are important aspects that should be considered in order to improve integration between these services.
\end{abstract}

\section{Keywords}

Knowledge; Professional; Physical activity; Basic Health Care.

\section{Resumo}

O objetivo deste estudo foi verificar o conhecimento dos profissionais da Estratégia Saúde da Familia (ESF) sobre o Programa Academia da Cidade (PAC) no Recife. Realizou-se um estudo transversal, descritivo e de abordagem quantitativa nas unidades de saúde da familia (USF) do Recife localizadas a no máximo 2 $\mathrm{km}$ de distância dos polos do PAC. Participaram do estudo 203 profissionais da ESF. O instrumento para a coleta de dados foi um questionário autoaplicado. As variáveis abordadas se referiam aos aspectos sociodemográficos, de formação profissional e relacionados ao conhecimento sobre o PAC. A coleta de dados ocorreu no periodo de julbo a agosto de 2015, mediante visitas pré-agendadas nas USF. Os dados foram tabulados por meio do programa EpiDataEntry e analisados no software SPSS. Dos profissionais entrevistados, $89,2 \%$ eram do sexo feminino, $37,4 \%$ possuíam entre 30 e 39 anos, 95,0\% declararam conbecer o PAC, 76,5\% conbecem os polos do seu território de atuação, 48,4\% afirmaram conhecer os objetivos do programa. Por outro lado, 58,9\% não conhecem outros locais onde são desenvolvidas ações do PAC, além dos polos, como também não conhecem todas as ações desenvolvidas pelo Programa. Ora, constata-se que os profissionais da ESF conbecem o PAC e seus objetivos, bem como os polos de seu distrito sanitário. No entanto, menos da metade conhece outros locais em que o programa funciona, como nas USF, além de reconhecer apenas algumas ações como sendo do PAC. Portanto, revelam-se aspectos importantes que devem ser considerados para potencializar o trabalho integrado entre estes serviços.

\section{Palavras-chave}

Conhecimento; Profissional; Atividade física; Atenção Básica à Saúde.

\section{Introduction}

The National Health System (NHS) incorporates the

1 Higher School of Physical Education, University of Pernambuco, Graduate Certificate Program.

2 Associate Graduate Physical Education Program, University of Pernambuco/Federal University of Paraíba. broad concept of health resulting from the lifestyles of populations ${ }^{1}$. Different strategies were established to contribute positively to health from this perspective, including the Family Health Strategy (FHS), the primary form of organizing Basic Health Care (BHC) in the NHS, aimed at implementing a multiprofes- 
sional collective health model centered on the family and the community ${ }^{2,3}$.

Furthermore, municipal initiatives were created to improve existing health measures. For example, the Academia da Cidade Program (ACP) in Recife was implemented in 2002 as a health promotion strategy in BHC, with the aim of contributing to collective health promotion by encouraging and directing physical activities, leisure and healthy eating. The guiding principles of this program are subject autonomy, social protagonism, intersectoriality, interdisciplinarity, transversality, health and leisure - citizens' rights ${ }^{4}$.

In light of the high prevalence of physical inactivity and its negative effects on health, considered a serious public health problem worldwide 5 , continuous efforts to implement a number of approaches in $\mathrm{BHC}$ have produced positive results in promoting physical activity ${ }^{6}$. This can be explained by the wide coverage of BHC, its objectives, and the performance and integration of its multiprofessional teams, which have allowed the establishment of interdisciplinary actions that favor the planning and development of interventions in order to increase physical activity, thereby contributing to improving public health? ${ }^{7}$.

In this respect, the situation in Recife is particularly interesting, since its BHC network is composed of an institutionalized program of physical activity promotion ${ }^{4}$, which, acting in conjunction with the FHS, may increase the population's access to ACP interventions. To that end, physical activity counseling for primary care users is an important component of health promotion ${ }^{8}$; this is a brief intervention that can be conducted by health professionals, involving anything from a simple conversation to a more specific and personalized discussion with a focus on behavioral changes ${ }^{9,10}$.

Randomized trials demonstrated that adults of both sexes can increase their physical activity after receiving counseling in $\mathrm{BHC}^{11-17}$. However, a systematic review showed that the two main barriers to physical activity counseling perceived by primary care professionals were lack of time and limited knowledge ${ }^{18}$. In a study in Brazil, health professionals reported regularly giving advice; however, their knowledge of physical activity recommendations was classified as $l o w^{19}$. These studies reinforce the importance of knowledge regarding the programs and services that promote physical activity in the districts covered by primary health care professionals, in order to allow them to encourage users treated at family health units to engage in regular physical activity, through access to the nearest facilities in the municipal health network.

Thus, considering the scenario in Recife and the importance of basic health care professionals as protagonists in the promotion of physical activity in the NHS, the aim of this study was to assess the knowledge of FHS professionals regarding the ACP in Recife.

\section{Methods}

This is a descriptive, cross-sectional study with a quantitative approach. The study sites were FHUs in Recife located at most $2 \mathrm{~km}$ from ACP centers - the distance established as sufficiently close to allow better dialogue between the two. The source used to determine the addresses of the ACP centers and FHUs was the National Registry of Health Establishments (NRHE). The Google Maps application was used to calculate the walking distance between the centers and the units.

The study population consisted of FHU professionals. The sample was composed of at least one professional from each category (doctor, nurse, nurse technician, community health agent, dentist and oral health technician) of the FHU. Professionals who were on medical, maternity or study leave, or on vacation during the study period were excluded. 
The city of Recife has 115 FHUs and 38 ACP centers, distributed in eight sanitary districts; 68 of the units were within $2 \mathrm{~km}$ of a center, resulting in a potential sample of 408 professionals (considering the aforementioned criterion). However, collection was impossible in 20 of these units due to problems in scheduling visits for units in difficult-to-access areas, or for having failed to collect data more than once at some of the units.

The data collection instrument used was a self-applied questionnaire, designed for FHU professionals, and containing objective questions based on recent studies on the issue ${ }^{20}$. The questionnaire was organized into four sections (Chart 1), as follows: (1) sociodemographic profile and professional training, (2) knowledge of physical activity, (3) knowledge of the ACP, (4) integration with the ACP.

\begin{tabular}{|l|l|}
\hline \multicolumn{1}{|c|}{ Population } & \multicolumn{1}{c|}{ Section and variables analyzed } \\
\hline & Sociodemographic \\
& - Sex \\
& - Age \\
& - Schooling \\
& - Training \\
& - Time working in the network \\
FHU professionals & - On-the-job training to work in other programs \\
& - Number of locations where they work \\
\cline { 2 - 2 } & Knowledge of ACP \\
& - Knows the ACP \\
& - How they became aware of the ACP \\
& - Knowledge of centers located in the sanitary district they work in \\
& - Degree of knowledge regarding the objective of the ACP \\
& - Knowledge of ACP activities \\
& - Knowledge of locations, other than the centers, where ACP activities are conducted \\
\hline
\end{tabular}

CHART 1 - Distribution of the variables analyzed.

Data collection involved nine duly trained graduate students (eight hours of training on lifestyle and health conducted by members of the research group with experience in the area) from the University of Pernambuco. Data collection occurred at pre-arranged visits to the FHUs of the sanitary districts between July and August 2015. Contact was initially made by basic health care support staff to determine the day of the FHU team meeting, in order to schedule collection on that day; when professionals were absent, the researchers returned two further times to the FHU on different days and times.

The data tabulation procedure was carried out using the EpiDataEntry 3.1 program. SPSS 10.0 software was applied for data analysis, and the results presented as relative and absolute frequencies.

Theresearch project to which thisstudyis linked wasapproved by theHuman Research Ethics Committee of the University of Pernambuco - CAAE: 45622215.8.0000.5192. All the subjects were volunteers and gave their informed consent.

\section{Results}

At the 48 FHUs where collections were made, 71 professionals were lost and 14 refused to take part in the study, for a final total of 203 professionals. Of these, distribution in terms of professional training was as follows: $30.6 \%$ community health agents, $18.7 \%$ nurses, $15.8 \%$ nurse technicians, $13.8 \%$ doctors, $12.8 \%$ dentists and $8.3 \%$ technicians and/or oral health assistants. In addition, $33.5 \%$ were from sanitary district II, $89.2 \%$ were women and $37.4 \%$ were aged between 30 and 39 years (table 1 ).

With respect to initial formation, more than half (59.6\%) had a university education, studied collective health (92.4\%) and health promotion $(87.5 \%)$ at the undergraduate level or in a technical course, and had graduated between 10 and 19 years 
before (33.1\%). In BHC, 32.1\% had worked for 11 to 15 years and $80.6 \%$ participated in on-the-job training in order to work in other municipal health programs (table 1).

TABLE 1 - Sociodemographic profile and training of family health teams in Recife, 2015.

\begin{tabular}{|c|c|c|c|c|c|c|c|c|c|c|c|c|c|c|}
\hline \multirow[t]{2}{*}{ Variables } & \multicolumn{2}{|c|}{$\begin{array}{l}\text { Community } \\
\text { health agent }\end{array}$} & \multicolumn{2}{|c|}{ Nurse } & \multicolumn{2}{|c|}{$\begin{array}{l}\text { Nurse } \\
\text { technician }\end{array}$} & \multicolumn{2}{|c|}{ Doctor } & \multicolumn{2}{|c|}{ Dentist } & \multicolumn{2}{|c|}{$\begin{array}{c}\text { Oral health technical } \\
\text { assistant }\end{array}$} & \multicolumn{2}{|c|}{ Total } \\
\hline & $n$ & $\%$ & $n$ & $\%$ & $n$ & $\%$ & $n$ & $\%$ & $n$ & $\%$ & $n$ & $\%$ & $n$ & $\%$ \\
\hline \multicolumn{15}{|l|}{ Sex } \\
\hline Female & 54 & 87.1 & 37 & 97.4 & 29 & 90.6 & 20 & 71.4 & 24 & 92.3 & 17 & 100.0 & 181 & 89.2 \\
\hline Male & 8 & 12.9 & 1 & 2.6 & 3 & 9.4 & 8 & 28.6 & 2 & 7.7 & - & - & 22 & 10.8 \\
\hline \multicolumn{15}{|l|}{ Age range* } \\
\hline 20 to 29 years & 7 & 11.9 & 1 & 2.6 & - & - & 2 & 7.4 & - & - & 2 & 11.8 & 12 & 6.1 \\
\hline 30 to 39 years & 16 & 27.1 & 16 & 42.1 & 14 & 45.2 & 4 & 14.8 & 13 & 50.0 & 11 & 64.7 & 74 & 37.4 \\
\hline 40 to 49 years & 20 & 33.9 & 10 & 26.3 & 12 & 38.7 & 8 & 29.6 & 5 & 19.2 & 4 & 23.5 & 59 & 29.8 \\
\hline 50 to 59 years & 14 & 23.7 & 6 & 15.8 & 4 & 12.9 & 9 & 33.3 & 7 & 26.9 & - & - & 40 & 20.2 \\
\hline 60 to 69 years & 2 & 3.4 & 5 & 13.2 & 1 & 3.2 & 4 & 14.8 & 1 & 3.8 & - & - & 13 & 6.6 \\
\hline \multicolumn{15}{|l|}{ Schooling } \\
\hline \multirow{2}{*}{$\begin{array}{l}\text { Secondary and university } \\
\text { technical course }\end{array}$} & 49 & 79.0 & - & - & 21 & 65.6 & - & - & - & - & 12 & 70.6 & 82 & 40.4 \\
\hline & 13 & 21.0 & 38 & 100.0 & 11 & 34.4 & 28 & 100.0 & 26 & 100.0 & 5 & 29.4 & 121 & 59.6 \\
\hline \multicolumn{15}{|l|}{ Studied collective health * } \\
\hline Yes & 31 & 86.1 & 37 & 100.0 & 31 & 100.0 & 27 & 96.4 & 23 & 88.5 & 9 & 69.2 & 158 & 92.4 \\
\hline No & 5 & 13.9 & - & - & - & - & 1 & 3.6 & 3 & 11.5 & 4 & 30.8 & 13 & 7.6 \\
\hline \multicolumn{15}{|l|}{ Studied health promotion* } \\
\hline Yes & 32 & 88.9 & 35 & 94.6 & 28 & 93.3 & 22 & 78.6 & 21 & 80.8 & 9 & 81.8 & 147 & 87.5 \\
\hline No & 4 & 11.1 & 2 & 5.4 & 2 & 6.7 & 6 & 21.4 & 5 & 19.2 & 2 & 18.2 & 21 & 12.5 \\
\hline \multicolumn{15}{|l|}{ Time since graduation* } \\
\hline 1 to 9 years & 7 & 87.5 & 4 & 11.1 & 7 & 87.5 & 5 & 17.9 & 3 & 11.5 & 3 & 100.0 & 29 & 26.6 \\
\hline 10 to 19 years & 1 & 12.5 & 19 & 52.8 & 1 & 12.5 & 4 & 14.3 & 11 & 42.3 & - & - & 36 & 33.1 \\
\hline 20 to 29 years & - & - & 7 & 19.4 & - & - & 8 & 28.6 & 5 & 19.2 & - & - & 20 & 18.3 \\
\hline 30 to 39 years & - & - & 6 & 16.7 & - & - & 10 & 35.7 & 7 & 26.9 & - & - & 23 & 21.1 \\
\hline 40 to 49 years & - & - & - & - & - & - & 1 & 3.6 & - & - & - & - & 1 & 0.9 \\
\hline \multicolumn{15}{|l|}{ Time working in $\mathrm{BHC}^{*}$} \\
\hline 1 to 5 years & 16 & 26.2 & 1 & 2.9 & 6 & 19.4 & 5 & 18.5 & 4 & 15.4 & 4 & 23.5 & 36 & 18.4 \\
\hline 6 to 10 years & 7 & 11.5 & 9 & 26.5 & 15 & 48.4 & 4 & 14.8 & 7 & 26.9 & 8 & 47.1 & 50 & 25.5 \\
\hline 11 to 15 years & 17 & 27.9 & 14 & 41.2 & 10 & 32.3 & 7 & 25.9 & 10 & 38.5 & 5 & 29.4 & 63 & 32.1 \\
\hline 16 to 20 years & 14 & 23.0 & 7 & 20.6 & - & - & 8 & 29.6 & 1 & 3.8 & - & - & 30 & 15.3 \\
\hline 21 to 25 years & 7 & 11.5 & 2 & 5.9 & - & - & 1 & 3.7 & 4 & 15.4 & - & - & 14 & 7.1 \\
\hline 26 to 30 years & - & - & 1 & 2.9 & - & - & 2 & 7.4 & - & - & - & - & 3 & 1.5 \\
\hline \multicolumn{15}{|c|}{ Underwent on-the-job training to work in other programs* } \\
\hline Yes & 54 & 93.1 & 29 & 80.6 & 25 & 78.1 & 20 & 71.4 & 20 & 76.9 & 10 & 62.5 & 158 & 80.6 \\
\hline No & 4 & 6.9 & 7 & 19.4 & 7 & 21.9 & 8 & 28.6 & 6 & 23.1 & 6 & 37.5 & 38 & 19.4 \\
\hline \multicolumn{15}{|l|}{ Sanitary district (SD) } \\
\hline SDI & 7 & 11.3 & 7 & 18.4 & 6 & 18.8 & 5 & 17.9 & 5 & 19.2 & - & - & 30 & 14.8 \\
\hline SD \| & 17 & 27.4 & 12 & 31.6 & 9 & 28.1 & 10 & 35.7 & 10 & 38.5 & 10 & 58.8 & 68 & 33.5 \\
\hline SD III & 6 & 9.7 & 2 & 5.3 & 3 & 9.4 & 2 & 7.1 & 1 & 3.8 & 1 & 5.9 & 15 & 7.4 \\
\hline SD IV & 11 & 17.7 & 4 & 10.5 & 5 & 15.6 & 5 & 17.9 & 5 & 19.2 & 2 & 11.8 & 32 & 15.8 \\
\hline SDV & 12 & 19.4 & 5 & 13.2 & 1 & 3.1 & 1 & 3.6 & 2 & 7.7 & 1 & 5.9 & 22 & 10.8 \\
\hline SD VI & 2 & 3.2 & 2 & 5.3 & 3 & 9.4 & 1 & 3.6 & 1 & 3.8 & 1 & 5.9 & 10 & 4.9 \\
\hline SDVII & 3 & 4.8 & 3 & 7.9 & 3 & 9.4 & 2 & 7.1 & - & - & - & - & 11 & 5.4 \\
\hline SDVIII & 4 & 6.5 & 3 & 7.9 & 2 & 6.3 & 2 & 7.1 & 2 & 7.7 & 2 & 11.8 & 15 & 7.4 \\
\hline
\end{tabular}

* Variable with lost values (no responses from some respondents). 
In relation to knowledge of the Academia da Cidade Program, 95.0\% declared being aware of the Program, 56.1\% knew about it from advertising campaigns promoted by the municipal government of Recife, and $76.5 \%$ stated that they knew the ACP centers in their sanitary district. With respect to the objectives of the program, $48.4 \%$ responded that they knew them, followed by $39.5 \%$ who scarcely knew them (table 2).

TABLE 2 - Knowledge of professionals from the family health teams in Recife about the City Gym Program, 2015.

\begin{tabular}{|c|c|c|c|c|c|c|c|c|c|c|c|c|c|c|}
\hline \multirow[t]{2}{*}{ Variables } & \multicolumn{2}{|c|}{$\begin{array}{c}\text { Community health } \\
\text { agent }\end{array}$} & \multicolumn{2}{|c|}{ Nurse } & \multicolumn{2}{|c|}{ Nurse technician } & \multicolumn{2}{|c|}{ Doctor } & \multicolumn{2}{|c|}{ Dentist } & \multicolumn{2}{|c|}{$\begin{array}{c}\text { Oral health } \\
\text { technical assistant }\end{array}$} & \multicolumn{2}{|c|}{ Total } \\
\hline & $\mathrm{n}$ & $\%$ & $n$ & $\%$ & $\mathrm{n}$ & $\%$ & $n$ & $\%$ & $\mathrm{n}$ & $\%$ & $\mathrm{n}$ & $\%$ & $n$ & $\%$ \\
\hline \multicolumn{15}{|l|}{ Knows the $A C P^{*}$} \\
\hline Yes & 61 & 98.4 & 37 & 100.0 & 29 & 90.6 & 24 & 85.7 & 24 & 96.0 & 16 & 94.1 & 191 & 95.0 \\
\hline No & 1 & 1.6 & - & - & 3 & 9.4 & 4 & 14.3 & 1 & 4.0 & 1 & 5.9 & 10 & 5.0 \\
\hline \multicolumn{15}{|c|}{ How they became aware of the ACP } \\
\hline \multicolumn{15}{|c|}{ RMG advertising campaign } \\
\hline Yes & 34 & 56.7 & 21 & 56.8 & 17 & 58.6 & 16 & 69.6 & 11 & 45.8 & 7 & 43.8 & 106 & 56.1 \\
\hline No & 26 & 43.3 & 16 & 43.2 & 12 & 41.4 & 7 & 30.4 & 13 & 54.2 & 9 & 56.3 & 83 & 43.9 \\
\hline \multicolumn{15}{|c|}{ Visiting the centers } \\
\hline Yes & 27 & 45.0 & 18 & 48.6 & 12 & 41.4 & 11 & 47.8 & 11 & 45.8 & 8 & 50.0 & 87 & 46.0 \\
\hline No & 33 & 55.0 & 19 & 51.4 & 17 & 58.6 & 12 & 52.2 & 13 & 54.2 & 8 & 50.0 & 102 & 54.0 \\
\hline \multicolumn{15}{|c|}{ Through ACP users } \\
\hline Yes & 9 & 15.0 & 10 & 27.0 & 6 & 20.7 & 4 & 17.4 & 3 & 12.5 & 4 & 25.0 & 36 & 19.0 \\
\hline No & 51 & 85.0 & 27 & 73.0 & 23 & 79.3 & 19 & 82.6 & 21 & 87.5 & 12 & 75.0 & 153 & 81.0 \\
\hline \multicolumn{15}{|c|}{ Department of Health meetings } \\
\hline Yes & 15 & 25.0 & 17 & 45.9 & 6 & 20.7 & 11 & 47.8 & 8 & 33.3 & 1 & 6.3 & 58 & 30.7 \\
\hline No & 45 & 75.0 & 20 & 54.1 & 23 & 79.3 & 12 & 52.2 & 16 & 66.7 & 15 & 93.8 & 131 & 69.3 \\
\hline \multicolumn{15}{|c|}{ Knowledge of existing centers in their district* } \\
\hline Yes & 49 & 80.3 & 30 & 83.3 & 22 & 75.9 & 17 & 77.3 & 15 & 62.5 & 10 & 66.7 & 143 & 76.5 \\
\hline No & 12 & 19.7 & 6 & 16.7 & 7 & 24.1 & 5 & 22.7 & 9 & 37.5 & 5 & 33.3 & 44 & 23.5 \\
\hline \multicolumn{15}{|c|}{ Knowledge of ACP objectives* } \\
\hline Do not know & 2 & 3.3 & 2 & 5.4 & 3 & 10.3 & 1 & 4.3 & - & - & 1 & 6.3 & 9 & 4.7 \\
\hline Know a little & 23 & 37.7 & 13 & 35.1 & 8 & 27.6 & 11 & 47.8 & 10 & 41.7 & 10 & 62.5 & 75 & 39.5 \\
\hline Know & 25 & 41.0 & 21 & 56.8 & 16 & 55.2 & 11 & 47.8 & 14 & 58.3 & 5 & 31.3 & 92 & 48.4 \\
\hline Know a lot & 11 & 18.0 & 1 & 2.7 & 2 & 6.9 & - & - & - & - & - & - & 14 & 7.4 \\
\hline \multicolumn{15}{|c|}{ Aware of ACP interventions* } \\
\hline \multicolumn{15}{|c|}{ Physical activity promotion } \\
\hline Yes & 56 & 91.8 & 36 & 100.0 & 25 & 86.2 & 24 & 100.0 & 23 & 95.8 & 16 & 100.0 & 180 & 94.7 \\
\hline No & 5 & 8.2 & - & - & 4 & 13.8 & - & - & 1 & 4.2 & - & - & 10 & 5.3 \\
\hline \multicolumn{15}{|c|}{ Physical assessment } \\
\hline Yes & 46 & 75.4 & 35 & 97.2 & 18 & 62.1 & 22 & 91.7 & 21 & 87.5 & 13 & 81.3 & 155 & 81.6 \\
\hline No & 15 & 24.6 & 1 & 2.8 & 11 & 37.9 & 2 & 8.3 & 3 & 12.5 & 3 & 18.8 & 35 & 18.4 \\
\hline Health educatio & & & & & & & & & & & & & & \\
\hline Yes & 48 & 78.7 & 31 & 86.1 & 18 & 62.1 & 22 & 91.7 & 22 & 91.7 & 12 & 75.0 & 153 & 80.5 \\
\hline No & 13 & 21.3 & 2 & 5.6 & 5 & 17.2 & 2 & 8.3 & 2 & 8.3 & 4 & 25.0 & 28 & 14.7 \\
\hline Outings & & & & & & & & & & & & & & \\
\hline Yes & 18 & 29.5 & 13 & 36.1 & 7 & 24.1 & 9 & 37.5 & 11 & 45.8 & 6 & 37.5 & 64 & 33.7 \\
\hline No & 43 & 70.5 & 23 & 63.9 & 22 & 75.9 & 15 & 62.5 & 13 & 54.2 & 6 & 37.5 & 122 & 64.2 \\
\hline Referral and cou & f public & th users & & & & & & & & & & & & \\
\hline Yes & 10 & 16.4 & 13 & 36.1 & 5 & 17.2 & 10 & 41.7 & 6 & 25.0 & 2 & 12.5 & 46 & 24.2 \\
\hline No & 51 & 83.6 & 23 & 63.9 & 24 & 82.8 & 14 & 58.3 & 18 & 75.0 & 4 & 25.0 & 134 & 70.5 \\
\hline Knowledge of o & tions* & & & & & & & & & & & & & \\
\hline Yes & 25 & 41.0 & 20 & 55.6 & 9 & 31.0 & 8 & 33.3 & 12 & 50.0 & 4 & 25.0 & 78 & 41.1 \\
\hline No & 36 & 59.0 & 16 & 44.4 & 20 & 69.0 & 16 & 66.7 & 12 & 50.0 & 12 & 75.0 & 112 & 58.9 \\
\hline
\end{tabular}

* Variable with lost values (no response from some respondents). RMG: Recife Municipal Government. 
When questioned about the ACP interventions, 94.7\% confirmed being aware that physical activity was promoted by the program; $81.6 \%$, physical assessment and $80.5 \%$, health education. Only $24.2 \%$ knew that the program practiced referrals and counter-referrals. Moreover, $58.9 \%$ of the FHS professionals from Recife did not know locations, other than the centers, that conducted ACP activities, such as FHUs and other social-oriented facilities in the area (table 2).

\section{Discussion}

The results obtained reveal that FHS professionals from Recife are familiar with the ACP and the centers (requalified or purpose-built public spaces where the systematic activities of the program are carried out) located in their sanitary district. This is relevant because the program has been part of BHC in the city since its implementation in $2002^{4}$, a first step in acquiring broader knowledge regarding the ACP.

Even though cause and effect analyses were not conducted in this study, a number of points related to the profile of these professionals deserve attention, since they are correlated with their knowledge of the ACP. For example, having studied collective health and health promotion, given that one of the main factors that facilitates interdisciplinarity in teamwork is the training of health professionals, when adapted to the reality of the team ${ }^{21}$.

Also in regard to the profile of these professionals, most had been working in $\mathrm{BHC}$ for more than six years and reported having undergone on-the-job training to be able to work in other health programs in Recife. In this respect, Coutinho ${ }^{22}$ states that the coordination and integration of knowledge in different health areas, and even in other fields, is essential in the teamwork process and represents a challenge for changes in health practices. It is important to underscore that both professionals and users still operate under traditional treatment-oriented actions, hindering effective health promotion at the different facilities ${ }^{23}$.

It is therefore vital that all the professionals assume joint responsibility for the program's success, avoiding discontinuity between health care actions, and an important strategy is permanent education, made possible by partnerships between the health sectors ${ }^{24}$ - in this case the ACP and FHS.

Most of the professionals became aware of the ACP from municipal government advertising campaigns; when asked about more detailed information regarding the program - objectives, interventions and different facilities -, even though nearly half reported knowing the objectives of the ACP, the percentage of those who scarcely knew it also rose. In the same respect, when questioned about the interventions developed, most were aware of those that promoted physical activity. However, practicing referrals and counter-referrals, which is directly linked to communication between FHS and ACP professionals, was not well-known as being one of its activities.

Based on the findings obtained, it was possible to determine that more detailed information remains limited among these professionals, despite the fact that most of them reported knowing the ACP. This may influence how these professionals related to the program, hindering integrated work. Given that they act as key actors for promoting healthy behavior in their communities ${ }^{19}$, the more and better the knowledge they have regarding the ACP, the greater the possibilities for counseling physical activities, especially in the program. The following should be considered: physical activity counseling conducted by BHC professionals is an important health promotion strategy ${ }^{8}$; moreover, there is consensus among health professionals from different countries that it is very important to promote this issue in $\mathrm{BHC}^{25}$. 
When FHS professionals were asked about locations, other than the centers, where routine interventions take place, more than half were unfamiliar with them, revealing shortcomings in the relationship between these two $\mathrm{BHC}$ facilities in Recife, given that the FHU itself is a facility where the ACP carries out its activities sporadically and systematically. Defined as extrapolated activities, these were implemented in 2009 in order to broaden coverage in the area by integrating with the FHS ${ }^{4}$. This is another result that can interfere negatively with the performance of these professionals as promoters of physical activity that encourage people to make use of in the different ACP centers in the area.

Feitosa ${ }^{26}$ investigated aspects that led users to participate in the ACP in Recife, and found that adherence to physical activities was a result of the counseling provided by health professionals at the unit located in the same district as the center. This reinforces the need for broader knowledge of the program on the part of FHS professionals, which was not found in this study.

Kahn et al. ${ }^{27}$ identified three high-impact approaches to promote physical activity: 1) informative approaches aimed at decision making in order to improve knowledge and attitudes; 2) behavioral and social approach to promote independence and qualification to change or maintain behavior; and 3) environmental and political approaches. Cleland et al..$^{28}$ suggests the combined use of these strategies to increase physical activity in the population, since, in addition to influencing intersectorial communication, community participation in the preparation and planning of actions also provides information about the physical activity options available. In this respect, the scenario in Recife has the potential for joint development of these approaches. However, greater and more qualified integration is required between FHS professionals, the ACP and other health services.

All of this highlights the urgent need for permanent education among BHC professionals in order to broaden their knowledge of the issue within their own context, as demonstrated in other studies ${ }^{18,19}$. Therefore, after completing training courses, the physical activity counseling provided by BHC doctors and nurses has proven to be effective in promoting physical activity. Other research found that after the course, professionals showed an increase in correct responses in relation to the weekly frequency of physical activity for health and improved knowledge that the benefits can be achieved in accumulated or continuous periods. Furthermore, they reported being able to motivate users to become involved in regular physical activity by means of knowledge acquired through educational programs ${ }^{5,29-30}$.

Based on the findings observed, it can be concluded that FHS professionals have limited knowledge of the ACP, which demonstrates limited integration between the FHS and the program. However, to ensure comprehensive care for users of the public health system, it is important to provide the means to overcome these barriers to knowledge, as a first step for a joint project. It is suggested that permanent education strategies be developed systematically among professionals in these services, in order to implement their guiding principles, as well as other forms of dialogue between them. These include implementing a matrix structure between ACP and FHS teams, establishing an integrated and continuous work schedule, and employing different methods to disseminate the program throughout the network - to align them with the national BHC and health promotion guidelines.

It is important to underscore that since this is a cross-sectional study, its limitations must be considered in order to determine the causes that hinder knowledge acquisition among these professionals. Accordingly, future investigations are needed on the same issue in different Brazilian environments, given that similar 
programs have been implemented in the country since the establishment of the national health promotion initiative.

\section{Acknowledgement}

To the research advisor for her academic contributions; to the Municipal Health Department of Recife, particularly the ACP of Recife, for the training opportunity provided to the professionals; and to the professionals at the FHUs of Recife who agreed to participate in the study for their significant contribution.

\section{Authors' contributions}

All the authors participated in the conception of the project or analysis and interpretation of the data, preparation of the article and critical review of the intellectual content, as well as giving their final approval of the version to be published.

\section{References}

1. Brasil. Ministério da Saúde. Secretaria de Vigilância em Saúde. Secretaria de Atenção à Saúde. Política Nacional de Promoção da Saúde: PNPS: revisão da Portaria MS/GM no 687, de 30 de março de 2006. Brasília: Ministério da Saúde, 2015.

2. Brasil. Ministério da Saúde. Secretaria de Atenção à Saúde. Departamento de Atenção Básica. Política Nacional de Atenção Básica. Brasília: Ministério da Saúde, 2012.

3. Gomes KO, Cotta RM, Araújo RM, Cherchiglia ML, Martins TCP. Atenção Primária à Saúde - a "menina dos olhos" do SUS: sobre as representações sociais dos protagonistas do Sistema Único de Saúde. Ciênc Saúde Coletiva. 2011;16(suppl. 1): 881-92.

4. Lemos EC, Gouveia GC, Luna CF. Programa Academia da Cidade: A experiência do Recife. In: Gurgel IG, Medeiros KR, Aragão AA, Santana RM. Gestão em Saúde Pública: Contribuições para a política - Recife: Editora UFPE, 2014. 139-53.

5. Lee IM, Shiroma EJ, Lobelo F, Puska P, Blair SN, Katzmarzyk PT. Effect of physical inactivity on major non-communicable diseases worldwide: an analysis of burden of disease and life expectancy. Lancet. 2012; 380 (9838): 219-29.

6. Costa EF, Guerra PH, dos Santos TI, Florindo AA. Systematic review of physical activity promotion by community health workers. Prev Med. 2015; 81: 114-21.

7. Ribeiro EHC, Avaliação da efetividade de intervenções de atividade física em adultos saudáveis usuários do Sistema Único de Saúde em uma região de baixo nível socioeconômico. [Tese de doutorado]. São Paulo: Universidade de São Paulo; 2015.

8. Jacobson DM, Strohecker L, Compton MT, Katz DL. Physical activity counseling in the adult primary care setting: position statement of the American College of Preventive Medicine. Am J Prev Med. 2005: 29(2):158-62.

9. National Institute for Health and Care Excellence: Four commonly use methods to increase physical activity. Disponível em http://guidance.nice.org.uk/ph2 March 2006. Acesso em: 12 fev 2016.

10. Siqueira FC, Nahas MV, Facchini LA, Piccini RX, Tomasi E, Thumé E, et al. Atividade física em profissionais de saúde do Sul e Nordeste do Brasil . Cad Saúde Pública, Rio de Janeiro. 2009; 25(9): 1917-28.

11. Hirvensalo M, Heikkinen E, Lintunen T, Rantanen T: The effect of advice by health care professionals on increasing physical activity of older people. Scand J Med Sci Sports. 2003, 13(4): 231-36.

12. Simons-Morton DG, Blair SN, King AC, Morgan TM, Applegate WB, O'Toole M, et al. Effects of physical activity counseling in primary care: The Activity Counseling Trial: A randomized controlled trial. JAMA. 2001; 286(6): 677-87.

13. Petrella RJ, Koval JJ, Cunningham DA, Paterson DH. Can primary care doctors prescribe exercise to improve fitness? The Step Test Exercise Prescription (STEP) project. Am J Prev Med. 2003; 24(4): 316-22.

14. Calfas KJ, Long BJ, Sallis JF, Wooten WJ, Pratt M, Patrick K: A controlled trial of physician counseling to promote the adoption of physical activity. Prev Med. 1996; 25(3): 225-33. 
15. Marcus BH, Goldstein MG, Jette A, Simkin-Silverman L, Pinto BM, Milan F, Washburn R, Smith K, Rakowski W, Dube CE: Training physicians to conduct physical activity counseling. Prev Med. 1997; 26(3): 382-88.

16. Sabti Z, Handschin M, Joss MK, Allenspach EC, Nuscheler M, Grize L, Braun-Fahrlander C: Evaluation of a physical activity promotion program in primary care. Fam Pract. 2010, 27(3): 279-84.

17. Orrow G, Kinmonth AL, Sanderson S, Sutton S. Effectiveness of physical activity promotion based in primary care: systematic review and meta-analysis of randomised controlled trials. BMJ. 2012; 344: 1389.

18. Hebert ET, Caughy MO, Shuval K. Primary care providers' perceptions of physical activity counselling in a clinical setting: a systematic review. Br J Sports Med. 2012; 46(9): 625-31.

19. Florindo AA, Mielke GI, de Oliveira Gomes GA, Ramos LR, Bracco MM, Parra DC, et al. Physical activity counseling in primary health care in Brazil: a national study on prevalence and associated factors. BMC Public Health. 2013; 13(1): 1-10.

20. Silva JRA. Práticas de monitoramento e avaliação nas intervenções para promoção da atividade física na atenção básica à saúde no estado de Pernambuco [dissertação de mestrado]. Recife: Universidade de Pernambuco; 2015.

21. Loch-Neckel G, Seemann G, Eidt HB, Rabuske MM, Crepaldi MA. Desafios para a ação interdisciplinar na atenção básica: implicações relativas à composição das equipes de saúde da família. Ciênc Saúde Coletiva. 2009; 14(Supl 1): 1463-72.

22. Coutinho SS. Competências do profissional de Educação Física na Atenção Básica à Saúde. [Tese de doutorado]. São Paulo: Universidade de São Paulo; 2011.

23. Silveira DR, Sena RD, Oliveira, RD. O processo de trabalho das equipes de saúde da família: implicações para a promoção da saúde. Rev Min Enferm. 2011; 15(2): 196-201.

24. Mendonça RD, Toled MTT, Lopes ACS. Incentivo à prática de aconselhamento. Escola Anna Nery Revista de Enfermagem. 2015; 19 (1): 140-46.

25. Parker WA, Steyn NP, Levitt, NS, Lombard CJ. They think they know but do they? Misalignment of perceptions of lifestyle modification knowledge among health professionals. Public Health Nutr.. 2011; 14(08): 1429-38.

26. Feitosa WMN. Programas de promoção da atividade física: estudo de caso acerca da implementação do Programa Academia da Cidade (PAC) em Recife entre 2002 e 2014 [tese de doutorado]. Recife: Centro de Pesquisas Aggeu Magalhães, Fundação Oswaldo Cruz; 2015.

27. Kahn EB, Ramsey LT, Brownson RC, Heath GW, Howze EH, Powell KE, et al. The effectiveness of interventions to increase physical activity: a systematic review. Am J Prev Med. 2002; 22: 73-107.

28. Cleland CL, Tully MA, Kee F, Cupples ME. The effectiveness of physical activity interventions in socio-economically disadvantaged communities: a systematic review. Prev Med. 2012; 54: 371-80.

29. Aittasalo M, Miilunpalo S, Kukkonen-Harjula K, Pasanen M. A randomized intervention of physical activity promotion and patient self-monitoring in primary health care. Prev Med. 2006; 42(1): 40-6.

30. Florindo AA, Costa EF, Sa TH, Santos TI, Velardi M, Andrade DR. Physical activity promotion in primary health care in Brazil: a counseling model applied to Community Health Workers. J Phys Act Health. 2014; 11: 1531-39.

\section{CORRESPONDING} AUTHOR

LETÍCIA LEMOS AYRES DA GAMA BASTOS lebastos17@hotmail.com
Rua Padre Lemos, $723 \mathrm{apt}^{\circ} 204$. Bloco F.

Bairro: Casa Amarela.

Cep: 52070-200.

Recife, PE, Brazil.
RECEIVED

REVISED

$02 / 12 / 2015$

$25 / 02 / 2016$

$31 / 03 / 2016$

$26 / 04 / 2016$

APPROVED $\quad 29 / 04 / 2016$ 